\title{
Up-Regulated Salivary Proteins of Brown Marmorated Stink Bug Halyomorpha halys on Plant Growth-Promoting Rhizobacteria-Treated Plants
}

\author{
Laurent Serteyn $^{1}$ (D) Olivier Lourme ${ }^{1} \cdot$ Lisa lannello $^{1} \cdot$ Dominique Baiwir $^{2,3} \cdot$ Gabriel Mazzucchelli $^{2} \cdot$ Marc Ongena $^{4}$. \\ Frederic Francis ${ }^{1}$
}

Received: 13 December 2020 / Revised: 9 May 2021 / Accepted: 6 June 2021 / Published online: 22 September 2021

(c) The Author(s), under exclusive licence to Springer Science+Business Media, LLC, part of Springer Nature 2021

\begin{abstract}
Plant Growth-Promoting Rhizobacteria (PGPR) induce systemic resistance (SR) in plants, decreasing the development of phytopathogens. The FZB42 strain of Bacillus velezensis is known to induce an SR against pathogens in various plant species. Previous studies suggested that it could also influence the interactions between plants and associated pests. However, insects have developed several strategies to counteract plant defenses, including salivary proteins that allow the insect escaping detection, manipulating defensive pathways to its advantage, deactivating early signaling processes, or detoxifying secondary metabolites. Because Brown Marmorated Stink Bug (BMSB) Halyomorpha halys is highly invasive and polyphagous, we hypothesized that it could detect the PGPR-induced systemic defenses in the plant, and efficiently adapt its salivary compounds to counteract them. Therefore, we inoculated a beneficial rhizobacterium on Vicia faba roots and soil, previous to plant infestation with BMSB. Salivary gland proteome of BMSB was analyzed by LC-MS/MS and a label-free quantitative proteomic method. Among the differentially expressed proteins, most were up-regulated in salivary glands of insects exposed to PGPR-treated plants for $24 \mathrm{~h}$. We could confirm that BMSB was confronted with a stress during feeding on PGPR-treated plants. The to-be-confirmed defensive state of the plant would have been rapidly detected by the invasive $H$. halys pest, which consequently modified its salivary proteins. Among the up-regulated proteins, many could be associated with a role in plant defense counteraction, and more especially in allelochemicals detoxification or sequestration.
\end{abstract}

Keywords Brown marmorated stink bug $\cdot$ LC-MS/MS $\cdot$ Plant growth-promoting rhizobacteria $\cdot$ Proteomics $\cdot$ Salivary glands

Laurent Serteyn

laurent.serteyn@uliege.be

1 Functional and Evolutionary Entomology, Gembloux AgroBio Tech, University of Liege, Passage des Deportes 2, B-5030 Gembloux, Belgium

2 Mass Spectrometry Laboratory, MolSys Research Unit, University of Liege, Liege, Belgium

3 GIGA Proteomics Facility, University of Liege, Liege, Belgium

4 Microbial Processes and Interactions Research Unit, Gembloux Agro-Bio Tech, University of Liege, Gembloux, Belgium

\section{Introduction}

Through their association with the roots, plant growthpromoting rhizobacteria (PGPR) can enhance the growth of host plants by providing nutrients or improving their accessibility, and producing growth hormones, volatiles, enzymes, and cofactors (Van Loon 2007; Lugtenberg and Kamilova 2009; Kumar et al. 2019). Some PGPR can also mitigate abiotic stresses: drought, salinity, heavy metals, and heat (Kumar et al. 2019). Lastly, PGPR could reduce biotic stresses by producing antimicrobial secondary metabolites, competing with root pathogens for nutrients and space, or inducing a systemic resistance (SR) in plants (Lugtenberg and Kamilova 2009; Andrić et al. 2020). In some cases, the plant defense responses are not directly activated by the SRinducing stimulus (here, the PGPR), a phenomenon called "priming": defenses of the primed plant would be faster, 
stronger, and more persistent when confronted to a following triggering stimulus (Martinez-Medina et al. 2016). Many studies showed that PGPR-induced SR could decrease the development of phytopathogens in aerial parts of the plant (Conrath et al. 2002; Van Loon 2007; Lugtenberg and Kamilova 2009; Pieterse et al. 2014). Increasing evidence suggests that PGPR could influence the interactions between the plant and associated pests, with outcomes on insect fitness depending on involved species and environmental conditions (Pineda et al. 2010, 2013). Nonetheless, the use of PGPR in integrated pest management is promising and deserves more attention from researchers.

Following recent advances in bacterial phylogeny, an "operational group Bacillus amyloliquefaciens", hereafter termed "B. amyloliquefaciens" for clarity, was proposed to include the soil-borne $B$. amyloliquefaciens and the plantassociated Bacillus siamensis and Bacillus velezensis (Fan et al. 2017). Bacteria in this group are known to promote plant growth (Matilla and Krell 2018) and a few studies suggested that they could reduce the fitness of insect pests in lab experiments (Zehnder et al. 1997; Gadhave and Gange 2016; Serteyn et al. 2020). B. amyloliquefaciens produces lipopeptides and volatile organic compounds that act as elicitors involved in the induction of plant resistance and priming (Ongena and Jacques 2008; Borriss et al. 2019). After the perception of these molecules by the root cells, defense pathways are activated, resulting in the chemical priming of the plant (Ongena and Jacques 2008; Choudhary and Johri 2009). The FZB42 strain of B. velezensis (formerly $B$. amyloliquefaciens), which colonizes roots surface by embedding in a biofilm, is commercially available as a biofertilizer and a control agent of soil-borne diseases (Borriss 2011). This strain is also well known to induce an SR against pathogens in various plant species, involving phytohormones like salicylic acid (SA), jasmonic acid (JA), and/or ethylene (Chowdhury et al. 2015; Tahir et al. 2017; Xie et al. 2017, 2018, 2019; Wu et al. 2018; Borriss et al. 2019; Farzand et al. 2019). Even if the latter hormonal pathways are notorious to be involved in defense against herbivores, the impact of FZB42-induced SR on insect pests is still unclear. Although, in our recently published study, we showed that FZB42 could negatively impact the reproduction of pea aphid Acyrthosiphon pisum Harris on Vicia faba L. plants, involving both JA and SA pathways (Serteyn et al. 2020).

However, insects have developed several strategies to counteract plant defenses, based on metabolic resistance, behavioral adaptation, or plant response neutralization (Stahl et al. 2018). The latter strategy mainly involves salivary proteins that allow the insect escaping detection, manipulating defensive pathways to its advantage, deactivating early signaling processes, or detoxifying secondary metabolites (Felton and Tumlinson 2008; Louis et al. 2012; Sharma et al. 2014; van Bel and Will 2016; Stahl et al.
2018). Especially, the saliva of phytophagous Hemipteran pests, such as aphids, was subjected to many studies, highlighting its crucial importance in plant-insect interactions (Sharma et al. 2014). Within the much less studied Pentatomidae family, the brown marmorated stink bug (BMSB), Halyomorpha halys (Stål) (Hemiptera: Pentatomidae), is a particularly interesting model. Coming from Eastern Asia, it has been accidentally introduced in North America, and then in Europe (Hoebeke and Carter 2003; Wermelinger et al. 2008). This invasive species will most probably colonize a large part of the world in the next decade (Zhu et al. 2012; Wallner et al. 2014; Cianferoni et al. 2018). Also, BMSB is highly polyphagous, feeding on dozens of plant families, including crops and orchards (Rice et al. 2014). These two main traits are likely associated with effective ways to counteract plant defenses.

The first description of BMSB salivary proteins, performed by Peiffer and Felton (2014), highlighted that plant defense could be induced by the salivary sheath. It was later completed by our descriptive proteomic analysis on salivary glands (Serteyn and Francis 2019). In a previous study, we highlighted that BMSB, when exposed to local plant defenses induced by its own presence, was able to rapidly modify its salivary compounds, up-regulating proteins potentially involved in plant defense counteraction (Serteyn et al. 2019). To our knowledge, no other study has worked on BMSB saliva or rhizobacteria-mediated interactions with its host plant.

Regarding our previous studies and the current knowledge on Hemipteran insect-plant interactions, we stated the hypothesis that BMSB could detect the PGPR-induced systemic defenses in plants and adapt its salivary compounds to counteract them. Therefore, we inoculated a beneficial rhizobacterium on plant roots and soil, infested the plants with BMSB, and then analyzed BMSB salivary glands by gel-free quantitative proteomics.

\section{Methods and Materials}

Insects, Bacteria, and Plants BMSB individuals were collected from Eastern China and were maintained inside cages in a quarantine rearing room in Belgium (16 h light, $\left.28 \pm 1{ }^{\circ} \mathrm{C}, 56.5 \pm 3 \% \mathrm{RH}\right)$. The insects were fed broad bean plants (Vicia faba L. cv. "Grosse Ordinaire") and sunflower seeds (Helianthus annuus L. cv. unknown), replaced every two weeks with new ones.

The FZB42 strain of Bacillus velezensis, formerly $B$. amyloliquefaciens, was provided by Prof. R. Borriss of Humboldt University, Berlin, and was cryopreserved at $-80{ }^{\circ} \mathrm{C}$ in glycerol $20 \%$. Bacteria were grown on lysogeny broth (tryptone $10 \mathrm{gL}^{-1}$, yeast extract $5 \mathrm{gL}^{-1}, \mathrm{NaCl}$ $10 \mathrm{gL}^{-1}, \mathrm{pH}$ 7) with agar-agar $12 \mathrm{gL}^{-1}$ during $24 \mathrm{~h}$ at 
$30{ }^{\circ} \mathrm{C}$. Bacteria were then transferred into a liquid lysogeny broth and incubated at $30{ }^{\circ} \mathrm{C}$ with $200 \mathrm{rpm}$ agitation for $24 \mathrm{~h}$. The bacterial solution was cleaned twice by centrifugation at 5,000 rpm for $10 \mathrm{~min}$ and re-suspension of the pellets in autoclaved tap water. The optical density of bacterial solutions was measured with a spectrophotometer (Biochrom WPA, model: Biowave DNA) at $600 \mathrm{~nm}$ and the concentration of cells was adjusted to $5 \times 10^{8}$ cells per $\mathrm{mL}$.

Broad bean seeds were sterilized under agitation with ethanol $70 \%$ for $2 \mathrm{~min}$ and with sodium hypochlorite $6-14 \%$ (Emplura, Merck) for $8 \mathrm{~min}$, and then rinsed with sterilized water. To induce germination, boiling water was applied to seeds for $15 \mathrm{~s}$, and the seeds were soaked in sterilized water overnight. The seeds were soaked in the bacterial solution for 2 min ("P" for PGPR treatment), or sterilized water as a control treatment ("NP" for No PGPR). The seeds were then individually sewed in pots filled with loam (La Plaine Chassart, Belgium) and were put in a growing chamber ( $16 \mathrm{~h}$ light, $\left.25.5 \pm 0.5^{\circ} \mathrm{C}\right)$. Seven days later, the surface of the soil of the young plants - whose first leaves were fully developed - was treated with $15 \mathrm{ml}$ of the bacterial solution, or with sterilized water.

Preparation of Protein Samples Fifth-instar BMSB larvae were exposed to control or PGPR-treated broad bean plants ( 2 weeks old or at stage 12 on BBCH-scale). Four biological replicates per treatment were prepared, each consisting of 2 larvae restrained together to the apical, youngest leaves of one plant with tulle bags. After $24 \mathrm{~h}$ exposure, they were dissected as described in Serteyn and Francis (2019), to collect all 4 salivary glands of each system. The extraction of proteins of each sample was performed, following the protocol of Serteyn and Francis (2019). Protein contents were quantified using the RC-DC protein assay kit (Bio-Rad) and the reduction-alkylation of $20 \mu \mathrm{g}$ proteins per sample was performed, following the protocol described by Bauwens et al. (2013). The proteins of each sample were purified using the 2D-Clean Up Kit (GE Healthcare), and then the pellets were re-suspended in $50 \mathrm{mM}$ ammonium bicarbonate and digested in solution with trypsin (Pierce MS grade, Thermo Scientific): $16 \mathrm{~h}$ incubation at $37{ }^{\circ} \mathrm{C}$ with a ratio trypsin/total proteins (w:w) of $1 / 50 ; 3 \mathrm{~h}$ at $37{ }^{\circ} \mathrm{C}$ with a ratio of $1 / 100$ in $80 \%$ acetonitrile. After stopping the digestion by adding trifluoroacetic acid (TFA) $0.5 \%(\mathrm{v} / \mathrm{v})$, the samples were vacuum-dried using SpeedVac (Thermo Scientific). For each sample, $3.5 \mu \mathrm{g}$ protein digest was purified on a Ziptip C18 (Millipore), dried, and re-suspended in acidified water (0.1\% TFA). MassPrep Digestion Standard (Waters), 1 or 2 depending on the condition, was added at 100 fmoles $\mathrm{ADH}$ per injection. One microgram protein digest was injected into the LC system.
Mass Spectrometry The LC-MS/MS analyses were performed on an Acquity M-Class UPLC (Waters) hyphenated to a Q Exactive Plus (Thermo Scientific), in nanoelectrospray positive ion mode, in the Proteomics Facility of the GIGA (ULiège). The trap column was a Symmetry C18 $5 \mu \mathrm{m}(180 \mu \mathrm{m} \times 20 \mathrm{~mm})$ and the analytical column was a HSS T3 C18 $1.8 \mu \mathrm{m}(75 \mu \mathrm{m} \times 250 \mathrm{~mm})$ (Waters). The samples were loaded at $20 \mu \mathrm{Lmin}^{-1}$ on the trap column in $98 \%$ solvent A ( $0.1 \%$ formic acid in water) for $3 \mathrm{~min}$ and subsequently separated on the analytical column at a flow rate of $600 \mathrm{nLmin}^{-1}$ with the following linear gradient: initial conditions $2 \%$ solvent B ( $0.1 \%$ formic acid in acetonitrile); $5 \min 7 \%$ B; $135 \operatorname{min~} 30 \%$ B, 150 min $40 \%$ B; 154 min 90\% B until $158 \mathrm{~min}$, and then back to initial conditions at $162 \mathrm{~min}$ until $177 \mathrm{~min}$. The total run time was $180 \mathrm{~min}$. The mass spectrometer method was a TopN-MSMS method, where $\mathrm{N}$ was set to 12 , meaning that the spectrometer acquires one Full MS spectrum, selects the 12 most intense peaks in this spectrum, and makes a Full MS2 spectrum of each of these 12 compounds. The parameters for MS spectrum acquisition were: Mass Range from 400 to $1600 \mathrm{~m} / \mathrm{z}$; Resolution of 70,000; AGC Target of 1e6 or Maximum Injection Time of $50 \mathrm{~ms}$. The parameters for MS2 spectrum acquisition were: Isolation Window of $2.0 \mathrm{~m} / \mathrm{z}$; Normalized Collision Energy of 28; Resolution of 17,500; AGC Target of $1 \mathrm{e} 5$ or Maximum Injection Time of $50 \mathrm{~ms}$.

Data Processing Spectra were treated using the software Maxquant vs 1.5.2.8 (Maxquant, Germany), following exactly the procedure of Serteyn et al. (2019). Spectra were searched using NCBI database restricted to Hemiptera taxonomies (downloaded in 2018). Carbamidomethyl of cysteines and oxidation of methionine were set as variable modifications. Identification of a protein was considered reliable when its score was higher than 15 , with a FDR of $1 \%$ and at least 1 unique peptide. Afterward, each protein hit was quantified and expressed in label-free quantification (LFQ) intensities. To improve the identification of unknown protein hits, BLAST analyses were performed against the broader NCBI database restricted to Arthropoda taxonomies.

Data Analysis The dataset was treated following the procedure of Serteyn et al. (2019) to select the differentially expressed proteins between treatments. Using the software Perseus vs 1.6.2 (Maxquant, Germany), contaminants were removed from the dataset, LFQ intensities were $\log _{2}$-transformed, and samples were grouped according to the treatment. Proteins were considered present in a treatment when at least 2 out of the 4 biological replicates showed an MS signal, and proteins were considered absent when none of the 4 replicates showed a signal. To decrease the risk of false positives and negatives, protein hits that were identified in only one out of the 4 replicates in one of 


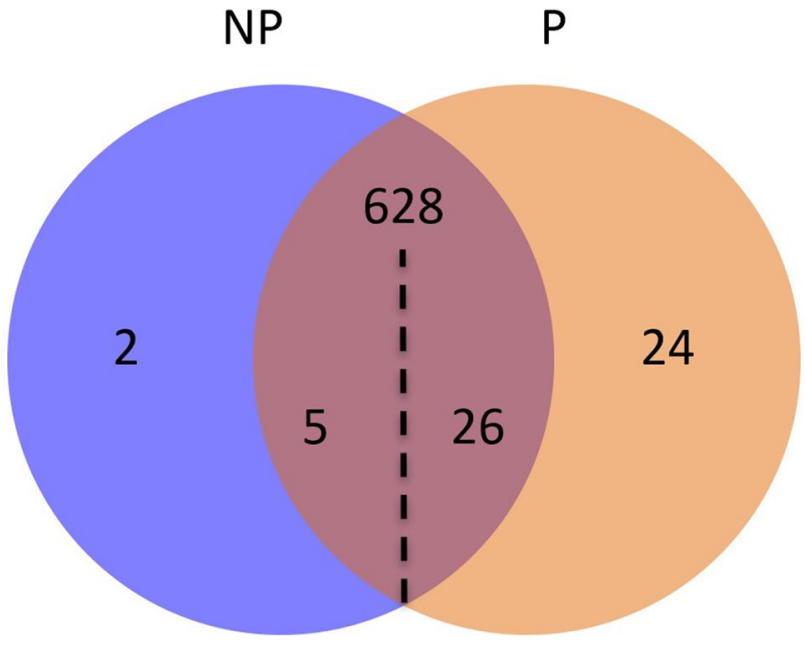

Fig.1 Venn diagram distributing proteins of Halyomorpha halys salivary glands according to the plant treatment ("NP": untreated plants; "P": plants inoculated with Bacillus velezensis FZB42)

the conditions were removed from the differential analysis. Additionally, two-samples $t$-tests with a 95\% confidence level $(\mathrm{P} \leq 0.05)$ were performed when at least 3 out of the 4 replicates of both treatments showed a signal. Each differentially expressed protein was annotated with a category of biological process, cellular component, and molecular function, using the software Blast2GO vs 5.2.5 (BioBam, Spain). Their amino-acid sequence was also searched for potential secretion signal, using the SignalP Server v5.0, and for predicted transmembrane domains, using the TMHMM Server v2.0. Proteins with a signal peptide and 0 or 1 transmembrane domain could be considered as potentially secreted in salivary fluid. The mass spectrometry proteomics data have been deposited to the ProteomeXchange Consortium via the PRIDE (Perez-Riverol et al. 2019) partner repository with the dataset identifier PXD021734.

\section{Results and Discussion}

In this LC-MS/MS analysis, we identified 1,453 proteins in dissected salivary glands of BMSB. After removing the proteins that were identified in only one of the replicates of a treatment, 654 proteins were considered for this comparative analysis according to PGPR inoculation to the host plant. Among the differentially expressed proteins, 50 proteins were up-regulated in salivary glands of insects exposed to PGPR-treated plants for $24 \mathrm{~h}$, and 7 were down-regulated, compared to control treatment (Fig. 1). Among these 57 differentially expressed proteins, 43 could be annotated using Blast2GO software (Fig. 2). Most of them could be associated with metabolic or cellular processes, especially with oxido-reduction effects. They exert their molecular function by binding to RNA or ATP, or by a catalytic activity (e.g., ATPase). The differentially expressed proteins could be mainly associated with intracellular compartment and cell membranes. Proteins with a putative role in insect-plant interactions and/or presenting a secretion signal peptide are
Biological process
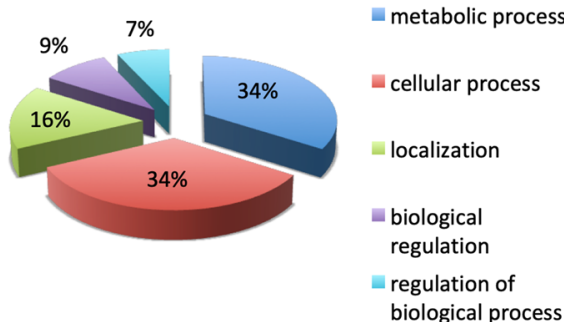

\section{Molecular function}
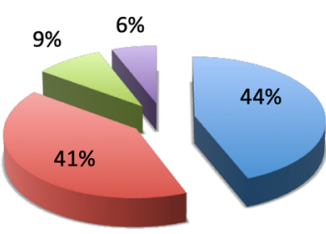

biological process
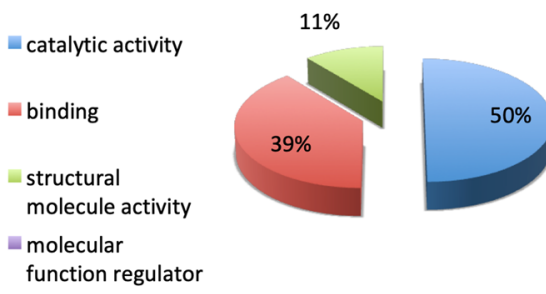

cellular anatomical

entity

intracellular

protein-

containing

complex
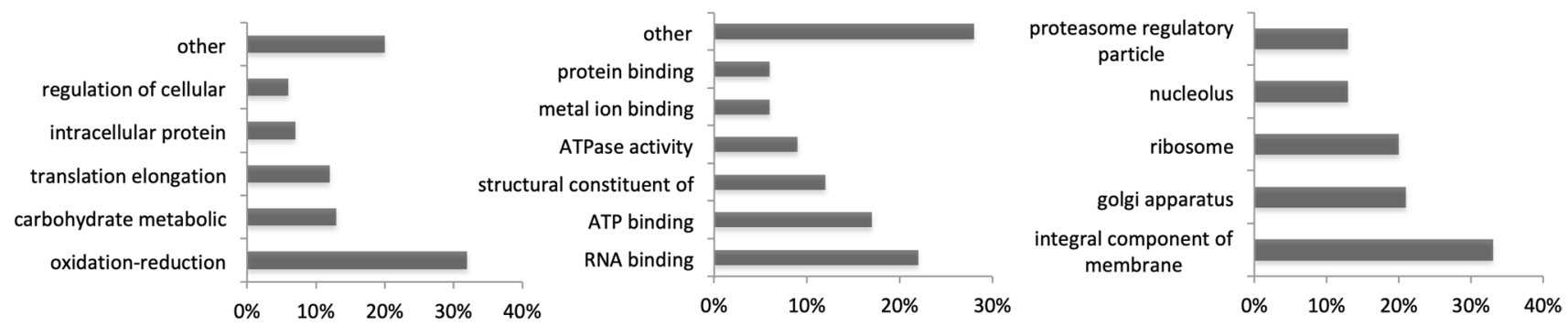

Fig. 2 Gene Ontology on differentially expressed proteins in Halyomorpha halys salivary glands according to PGPR inoculation 
Table 1 Differential proteins identified in salivary glands of Halyomorpha halys on PGPR-inoculated (P) or control (NP) plants, with a putative role in insect-plant interactions and/or presenting a secretion signal peptide

\begin{tabular}{|c|c|c|c|c|c|c|c|c|c|c|c|c|}
\hline \multirow{2}{*}{ Accession number } & \multirow{2}{*}{$\begin{array}{c}\text { Name of proteins and } \\
\text { organism }\end{array}$} & \multirow{2}{*}{$\begin{array}{c}\text { Secretion } \\
\text { signal } \\
\text { peptide? }\end{array}$} & \multirow{2}{*}{$\begin{array}{l}\text { Mol. } \\
\text { Weight } \\
\text { (kDa) }\end{array}$} & \multirow{2}{*}{ Score } & \multicolumn{3}{|c|}{ Mean LFQ intensity } & \multicolumn{3}{|c|}{$\log _{2}$ (Mean LFQ intensity) } & \multirow{2}{*}{$\begin{array}{c}\text { Putative role in } \\
\text { insect-plant } \\
\text { interactions }{ }^{\mathrm{d}}\end{array}$} & \multirow{2}{*}{$\begin{array}{l}\text { Biological } \\
\text { process }^{\mathrm{e}}\end{array}$} \\
\hline & & & & & NP & $\mathbf{P}$ & $\begin{array}{c}\text { Fold } \\
\text { change }^{b}\end{array}$ & $\mathbf{N P}$ & $\mathbf{P}$ & p-value ${ }^{c}$ & & \\
\hline \multicolumn{13}{|c|}{\begin{tabular}{|l} 
Down-regulated in PGPR treatment \\
\end{tabular}} \\
\hline XP_014279386.1 & $\begin{array}{l}\text { endochitinase At } 2 \mathrm{~g} 43620 \\
\text { [Halyomorpha halys] }\end{array}$ & yes & 25,42 & 19,53 & $8,23 \mathrm{E}+07$ & NS & & 26,29 & NS & & / & \begin{tabular}{|l|} 
chitin catabolic \\
process; cell wall \\
macromolecule \\
catabolic process
\end{tabular} \\
\hline XP_026756143.1 & $\begin{array}{l}\text { PI-PLC X domain- } \\
\text { containing protein } 3 \text { isoform } \\
\text { X1 [Galleria mellonella] }\end{array}$ & yes & 37,03 & 163,21 & $3,65 \mathrm{E}+08$ & $1,49 \mathrm{E}+08$ & 0,41 & 28,44 & 27,15 & 0,034 & / & $\begin{array}{l}\text { lipid metabolic } \\
\text { process }\end{array}$ \\
\hline XP_014289176.1 & $\begin{array}{l}\text { sorbitol dehydrogenase } \\
\text { [Halyomorpha halys] }\end{array}$ & & 37,70 & 109,74 & $8,23 \mathrm{E}+07$ & $7,23 \mathrm{E}+07$ & 0,88 & 26,29 & 26,11 & 0,027 & $\begin{array}{l}\text { Xenobiotic } \\
\text { metabolic } \\
\text { process }\end{array}$ & $\begin{array}{l}\text { oxidation- } \\
\text { reduction process }\end{array}$ \\
\hline \multicolumn{13}{|c|}{ Up-regulated in PGPR treatment } \\
\hline *XP_014294679.1 & $\begin{array}{l}\text { esterase FE4-like, partial } \\
\text { [Halyomorpha halys }]\end{array}$ & yes & 62,62 & 28,66 & NS & $1,23 \mathrm{E}+07$ & & NS & 23,55 & & $\begin{array}{l}\text { Resistance to } \\
\text { insecticides and } \\
\text { oxidative stress } \\
\end{array}$ & $\begin{array}{l}\text { amino-acids } \\
\text { metabolism }\end{array}$ \\
\hline *XP_014282104.1 & $\begin{array}{l}\text { flotillin-1 [Halyomorpha } \\
\text { halys] }\end{array}$ & & 47,96 & 13,61 & NS & $9,86 \mathrm{E}+06$ & & NS & 23,23 & & $\begin{array}{l}\text { Cellular response } \\
\text { to exogenous } \\
\text { dsRNA }\end{array}$ & $\begin{array}{l}\text { various } \\
\text { regulations }\end{array}$ \\
\hline XP_014284167.1 & $\begin{array}{l}\text { RWD domain-containing } \\
\text { protein } 1 \text { [Halyomorpha } \\
\text { halys] }\end{array}$ & & 26,87 & 11,33 & NS & $8,23 \mathrm{E}+06$ & & NS & 22,97 & & $\begin{array}{l}\text { Cellular response } \\
\text { to oxidative } \\
\text { stress }\end{array}$ & $\begin{array}{l}\text { various } \\
\text { regulations }\end{array}$ \\
\hline XP_017301089.1 & $\begin{array}{l}\text { glycogen phosphorylase } \\
\text { [Diaphorina citri }]\end{array}$ & & 61,98 & 11,81 & NS & $5,28 \mathrm{E}+08$ & & NS & 28,98 & & Immune response & $\begin{array}{l}\text { carbohydrate } \\
\text { metabolic } \\
\text { process }\end{array}$ \\
\hline *XP_014277690.1 & $\begin{array}{l}\text { probable salivary secreted } \\
\text { peptide [Halyomorpha } \\
\text { halys] }\end{array}$ & yes & 21,41 & 14,10 & NS & $3,33 \mathrm{E}+07$ & & NS & 24,99 & & Toxin activity & secretome \\
\hline XP_024217902.1 & $\begin{array}{l}\text { collagen alpha-2(IV) chain- } \\
\text { like isoform X2 } \\
\text { [Halyomorpha halys] }\end{array}$ & yes & 173,85 & 12,95 & NS & $1,93 \mathrm{E}+08$ & & NS & 27,53 & & / & $\begin{array}{l}\text { organismal } \\
\text { systems }\end{array}$ \\
\hline XP_014275880.1 & $\begin{array}{l}\text { uncharacterized protein } \\
\text { LOC106680586 isoform X2 } \\
\text { [Halyomorpha halys] }\end{array}$ & yes & 31,00 & 12,55 & NS & $9,97 \mathrm{E}+07$ & & NS & 26,57 & & / & unknown \\
\hline *XP_014279384.1 & $\begin{array}{l}\text { larval cuticle protein A2B } \\
\text { [Halyomorpha halys] }\end{array}$ & yes & 17,28 & 18,31 & NS & $1,50 \mathrm{E}+07$ & & NS & 23,84 & & / & $\begin{array}{l}\text { organismal } \\
\text { systems }\end{array}$ \\
\hline *XP_014281650.1 & $\begin{array}{l}\text { ATP-binding cassette sub- } \\
\text { family F member } 1 \\
\text { [Halyomorpha halys] }\end{array}$ & & 115,66 & 128,45 & $7,22 \mathrm{E}+07$ & $1,30 \mathrm{E}+08$ & 1,80 & 26,10 & 26,95 & 0,021 & Toxin excretion & $\begin{array}{l}\text { protein } \\
\text { metabolism }\end{array}$ \\
\hline XP_014290021.1 & $\begin{array}{l}\text { uncharacterized protein } \\
\text { LOC106689531 } \\
\text { [Halyomorpha halys] }\end{array}$ & yes & 47,81 & 189,61 & $1,78 \mathrm{E}+08$ & $2,38 \mathrm{E}+08$ & 1,33 & 27,41 & 27,83 & 0,050 & / & unknown \\
\hline *XP_014280439.1 & $\begin{array}{l}\text { heat shock } 70 \mathrm{kDa} \text { protein } 4 \\
\text { [Halyomorpha halys] }\end{array}$ & & 92,16 & 183,31 & $9,00 \mathrm{E}+07$ & $1,23 \mathrm{E}+08$ & 1,37 & 26,42 & 26,88 & 0,044 & $\begin{array}{l}\text { Cellular response } \\
\text { to heat and } \\
\text { oxidative stress }\end{array}$ & stress response \\
\hline XP_014292736.1 & $\begin{array}{l}\text { natterin-4 isoform X2 } \\
\text { [Halyomorpha halys] }\end{array}$ & & 17,30 & 137,42 & $5,64 \mathrm{E}+08$ & $6,67 \mathrm{E}+08$ & 1,18 & 29,07 & 29,31 & 0,002 & Toxin activity & secretome \\
\hline *XP_024215136.1 & $\begin{array}{l}\text { nascent polypeptide- } \\
\text { associated complex subunit } \\
\text { alpha, muscle-specific form } \\
\text { isoform X3 [Halyomorpha } \\
\text { halys] }\end{array}$ & yes & 294,98 & 323,31 & $8,02 \mathrm{E}+08$ & $1,39 \mathrm{E}+09$ & 1,73 & 29,58 & 30,37 & 0,022 & / & $\begin{array}{l}\text { transport and } \\
\text { catabolism }\end{array}$ \\
\hline *XP_014272751.1 & $\begin{array}{l}\text { protein disulfide-isomerase } \\
\text { isoform X1 [Halyomorpha } \\
\text { halys] }\end{array}$ & yes & 76,20 & 56,52 & $5,78 \mathrm{E}+09$ & $8,41 \mathrm{E}+09$ & 1,46 & 32,43 & 32,97 & 0,047 & / & $\begin{array}{l}\text { cell redox } \\
\text { homeostasis }\end{array}$ \\
\hline
\end{tabular}

Expression heatmap :
Lowest Highest

a according to SignalP-5.0 Server

${ }^{\mathrm{b}}$ based on control treatment

${ }^{\mathrm{c}}$ Student $t$-test with a $95 \%$ confidence level

$\mathrm{d}$ according to literature (see references in text) and UniProtKB

e according to Blast2GO software or KEGG pathways

NS No Signal

* already highlighted in our previous quantitative proteomic study (Serteyn et al. 2019)

presented in Table 1. Most of these proteins of interest were up-regulated upon PGPR treatment compared to the control. All these observations indicate that insect physiology is impacted by a stress during feeding. None of the proteins of interest presented a predicted transmembrane domain, meaning that all proteins of Table 1 with a secretion signal peptide could be secreted in saliva. Proteomics on salivary glands allows us to (1) identify cellular responses to exogenous stress, and (2) highlight some candidate proteins secreted into the plant through salivation processes.

Interestingly, several of these differentially expressed proteins were also up-regulated in our previous study 
on BMSB salivary glands (Serteyn et al. 2019). In the latter, we had induced plant defenses, using LOX activity as an indicator, by the previous feeding of 2 other BMSB individuals. Esterase FE4 and ATP-binding cassette $\mathrm{F}$ (ABC-F) are such proteins, whose expression profiles were comparable between both studies, and for which putative roles in plant-insect interactions could be associated. Esterase FE4 is mostly known to provide resistance to insecticides in bees and aphids (Tang et al. 2017; Ma et al. 2018). In Apis cerana Fabricius, the gene coding for esterase FE4 was also overexpressed after $\mathrm{H}_{2} \mathrm{O}_{2}$ treatment, probably conferring protection to the insect against oxidative stress. Indeed, Ma et al. (2018) showed that the silencing of that gene decreased the expression level of other genes reported to play important roles in the response to oxidative stress: superoxide dismutase, thioredoxin, catalase... It is noteworthy that reactive oxygen species (ROS) are part of early plant defensive responses against herbivores (Erb and Reymond 2019). Also, in a few cases, increased activity of esterase enzymes was measured in Lepidopteran insects exposed to plant phenolic glycosides ( $\mathrm{Li}$ et al. 2007). Therefore, the up-regulation of esterase FE4 could have been a protective reaction of BMSB individuals that were put on plants whose defenses were likely boosted by the PGPR. Furthermore, this enzyme was already observed in the watery saliva secreted by BMSB (Peiffer and Felton 2014). As it presents a secretion signal peptide, we confirm that it could be secreted with the saliva, therefore directly interacting with the plant. Further research is needed to assess whether the enzyme could directly counteract plant defenses in situ. ATP-binding cassettes $(\mathrm{ABC})$ are involved in the excretion of products resulting from detoxification processes in insects (Chahine and O'Donnell 2011; Birnbaum and Abbot 2018). Therefore, excretion fluids could be enhanced when insects are exposed to plant phenolic compounds (Chahine and O'Donnell 2011), which could be related to ABC. To validate this hypothesis in our case, further studies should assess whether BMSB would produce more excretion droplets while feeding on PGPR-treated plants.

On the contrary, the probable salivary secreted peptide, which could be associated with toxin activities of saliva, was up-regulated in insects feeding on PGPR-treated plants in this study, but down-regulated in insects exposed to BMSBinduced plant defense in our previous study (Serteyn et al. 2019). Natterin-4, initially found in a fish venom gland (Magalhães et al. 2006), was also up-regulated in the present study. This suggests that the previous presence of congeners on the plant could influence the need for toxin injection into plant tissues. Also, the up-regulation of secreted salivary proteins could mean that the salivation phases of BMSB on PGPR-treated plants were enhanced, which could increase the detoxification potential of proteins involved in plant defense counteraction.

Lastly, heat shock protein 70 (HSP70) is a well-known highly conserved protein, up-regulated in cells of many organisms exposed to environmental stresses (Schlesinger 1990). Notably, it is involved in the immunity systems of insects (Wojda 2017). As a chaperone protein, it was also associated with a protective reaction to oxidative (due to ROS) or biotic stresses (due to pathogenic attacks) (Tang et al. 2012). In our study, HSP70 was up-regulated in salivary glands of BMSB that fed on PGPR-inoculated plants, suggesting that the insect was exposed to oxidative stress. It was previously reported in salivary glands of other insects, like mosquitoes (Jariyapan et al. 2012), and only once, to our knowledge, in secreted saliva of aphids (Chaudhary et al. 2015).

\section{Conclusions}

To conclude, we can confirm that BMSB was confronted to a stress during feeding on PGPR-treated plants. Therefore, the inoculation of $B$. velezensis FZB42 probably primed the plant defenses. This tobe-confirmed primed state, though, would have been rapidly detected by the invasive pest $H$. halys, which consequently modified its salivary proteins. Among the up-regulated proteins, many could be associated with a role in plant defense counteraction, and more especially in allelochemicals detoxification or sequestration. We have pointed candidate proteins, esterase FE4 and ABC$\mathrm{F}$, whose essential function in adaptation of BMSB to host plant defenses should be assessed by further omics experiments.

With the present study, we set the basis of BMSB physiological plasticity, which will allow many other hypotheses to be tested. Do the salivary changes occur whatever the elicitor of plant defenses (e.g., insect saliva, phytohormones, other bacterial strains, other pests or pathogens...)? And at last, do these up-regulated salivary proteins effectively allow the insect to develop normally on primed plants?

Acknowledgements The authors thank professor R. Borriss of Humboldt University, who kindly provided the FZB42 strain of Bacillus velezensis.

Authors' Contributions LS, MO, and FF designed the experiments; LS, $\mathrm{OL}$, and LI led the experiments; DB and GM performed the proteomic analysis; LS, OL, and LI interpreted the results; LS wrote the manuscript; all authors read and approved the manuscript.

Data Availability The mass spectrometry proteomics data have been deposited to the ProteomeXchange Consortium via the PRIDE partner repository with the dataset identifier PXD021734. 
Code Availability Not applicable.

\section{Declarations}

Ethics approval Not applicable.

Consent to participate Not applicable.

Consent for publication Not applicable.

Conflicts of interest The authors declare that they have no conflict of interest.

\section{References}

Andrić S, Meyer T, Ongena M (2020) Bacillus responses to plantassociated fungal and bacterial communities. Front Microbiol 11:1-9. https://doi.org/10.3389/fmicb.2020.01350

Bauwens J, Millet C, Tarayre C et al (2013) Symbiont diversity in Reticulitermes santonensis (Isoptera: Rhinotermitidae): Investigation strategy through proteomics. Environ Entomol 42:882-887

Birnbaum SSL, Abbot P (2018) Insect adaptations toward plant toxins in milkweed-herbivores systems - a review. Entomol Exp Appl 166:357-366. https://doi.org/10.1111/eea.12659

Borriss R (2011) Use of plant-associated Bacillus Strains as biofertilizers and biocontrol agents in agriculture. In: Maheshwari D (ed) Bacteria in Agrobiology: Plant Growth Responses. SpringerVerlag, Berlin, pp 41-76

Borriss R, Wu H, Gao X (2019) Secondary metabolites of plant growth promoting rhizomicroorganisms. In: Singh $\mathrm{H}$, Keswani C, Reddy $\mathrm{M}$ et al (eds) Secondary Metabolites of Plant Growth Promoting Rhizomicroorganisms: Discovery and Applications. Springer, Singapore, pp 147-168

Chahine S, O'Donnell MJ (2011) Interactions between detoxification mechanisms and excretion in Malpighian tubules of Drosophila melanogaster. J Exp Biol 214:462-468. https://doi.org/10.1242/jeb.048884

Chaudhary R, Atamian HS, Shen Z et al (2015) Potato aphid salivary proteome: Enhanced salivation using resorcinol and identification of aphid phosphoproteins. J Proteome Res 14:1762-1778. https:// doi.org/10.1021/pr501128k

Choudhary DK, Johri BN (2009) Interactions of Bacillus spp. and plants - With special reference to induced systemic resistance (ISR). Microbiol Res 164:493-513. https://doi.org/10.1016/j. micres.2008.08.007

Chowdhury SP, Hartmann A, Gao XW, Borriss R (2015) Biocontrol mechanism by root-associated Bacillus amyloliquefaciens FZB42 - A review. Front Microbiol 6:1-11. https://doi.org/10.3389/fmicb. 2015.00780

Cianferoni F, Graziani F, Dioli P, Ceccolini F (2018) Review of the occurrence of Halyomorpha halys (Hemiptera: Heteroptera: Pentatomidae) in Italy, with an update of its European and World distribution. Biol 73:599-607. https://doi.org/10.2478/ s11756-018-0067-9

Conrath U, Pieterse CMJ, Mauch-mani B (2002) Priming in plantpathogen interactions. Trends Plant Sci 7:210-216. https://doi. org/10.1016/S1360-1385(02)02244-6

Erb M, Reymond P (2019) Molecular interactions between plants and insect herbivores. Annu Rev Plant Biol 70:527-557. https://doi. org/10.1146/annurev-arplant-050718-095910

Fan B, Blom J, Klenk HP, Borriss R (2017) Bacillus amyloliquefaciens, Bacillus velezensis, and Bacillus siamensis form an "Operational group B. amyloliquefaciens" within the B. subtilis species complex. Front Microbiol 8:1-15. https://doi.org/10.3389/fmicb. 2017.00022

Farzand A, Moosa A, Zubair M et al (2019) Suppression of Sclerotinia sclerotiorum by the induction of systemic resistance and regulation of antioxidant pathways in tomato using fengycin produced by Bacillus amyloliquefaciens FZB42. Biomolecules 9:613. https:// doi.org/10.3390/biom9100613

Felton GW, Tumlinson JH (2008) Plant-insect dialogs: complex interactions at the plant-insect interface. Curr Opin Plant Biol 11:457463. https://doi.org/10.1016/j.pbi.2008.07.001

Gadhave KR, Gange AC (2016) Plant-associated Bacillus spp. alter life-history traits of the specialist insect Brevicoryne brassicae L. Agric for Entomol 18:35-42. https://doi.org/10.1111/afe. 12131

Hoebeke ER, Carter ME (2003) Halyomorpha halys (Stål) (Heteroptera: Pentatomidae): A polyphagous plant pest from Asia newly detected in North America. Proc Entomol Soc Washingt 105:225-237

Jariyapan N, Roytrakul S, Paemanee A et al (2012) Proteomic analysis of salivary glands of female Anopheles barbirostris species A2 (Diptera: Culicidae) by two-dimensional gel electrophoresis and mass spectrometry. Parasitol Res 111:1239-1249. https://doi.org/ 10.1007/s00436-012-2958-y

Kumar A, Patel JS, Meena VS, Srivastava R (2019) Recent advances of PGPR based approaches for stress tolerance in plants for sustainable agriculture. Biocatal Agric Biotechnol 20:101271. https:// doi.org/10.1016/j.bcab.2019.101271

Li X, Schuler MA, Berenbaum MR (2007) Molecular mechanisms of metabolic resistance to synthetic and natural xenobiotics. Annu Rev Entomol 52:231-253. https://doi.org/10.1146/annurev.ento. 51.110104 .151104

Louis J, Singh V, Shah J (2012) Arabidopsis thaliana -Aphid Interaction. Arab B 10:e0159. https://doi.org/10.1199/tab.0159

Lugtenberg B, Kamilova F (2009) Plant-growth-promoting rhizobacteria. Annu Rev Microbiol 63:541-556. https://doi.org/10.1146/ annurev.micro.62.081307.162918

Ma M, Jia H, Cui X et al (2018) Isolation of carboxylesterase (esterase FE4) from Apis cerana cerana and its role in oxidative resistance during adverse environmental stress. Biochimie 144:85-97. https://doi.org/10.1016/j.biochi.2017.10.022

Magalhães GS, Junqueira-de-Azevedo ILM, Lopes-Ferreira M et al (2006) Transcriptome analysis of expressed sequence tags from the venom glands of the fish Thalassophryne nattereri. Biochimie 88:693-699. https://doi.org/10.1016/j.biochi.2005.12.008

Martinez-Medina A, Flors V, Heil M et al (2016) Recognizing plant defense priming. Trends Plant Sci 21:818-822. https://doi.org/10. 1016/j.tplants.2016.07.009

Matilla M, Krell T (2018) Plant growth promotion and biocontrol mediated by plant-associated bacteria BT. In: Egamberdieva D, Ahmad P (eds) Plant Microbiome Stress: Response. Springer Nature, Singapore, pp 45-80

Ongena M, Jacques P (2008) Bacillus lipopeptides: versatile weapons for plant disease biocontrol. Trends Microbiol 16:115-125. https://doi.org/10.1016/j.tim.2007.12.009

Peiffer M, Felton G (2014) Insights into the saliva of the brown marmorated stink bug Halyomorpha halys (Hemiptera: Pentatomidae). PLoS ONE 9:e88483. https://doi.org/10.1371/journal.pone.0088483

Perez-Riverol Y, Csordas A, Bai J et al (2019) The PRIDE database and related tools and resources in 2019: Improving support for quantification data. Nucleic Acids Res 47:D442-D450. https:// doi.org/10.1093/nar/gky1106

Pieterse CMJ, Zamioudis C, Berendsen RL et al (2014) Induced systemic resistance by beneficial microbes. Annu Rev Phytopathol 52:347-375. https://doi.org/10.1146/annur ev-phyto-082712-102340 
Pineda A, Dicke M, Pieterse CMJ, Pozo MJ (2013) Beneficial microbes in a changing environment: Are they always helping plants to deal with insects? Funct Ecol 27:574-586. https://doi.org/10.1111/ 1365-2435.12050

Pineda A, Zheng SJ, van Loon JJA et al (2010) Helping plants to deal with insects: The role of beneficial soil-borne microbes. Trends Plant Sci 15:507-514. https://doi.org/10.1016/j.tplants.2010.05. 007

Rice KB, Bergh CJ, Bergmann EJ et al (2014) Biology, ecology, and management of brown marmorated stink bug (Hemiptera: Pentatomidae). J Integr Pest Manag 5:1-13. https://doi.org/10.1603/ IPM14002

Schlesinger MJ (1990) Heat shock proteins. J Biol Chem 265:1211112114. https://doi.org/10.4149/av_2011_03_189

Serteyn L, Francis F (2019) Insight into salivary gland proteomes of two polyphagous stink bugs: Nezara viridula L. and Halyomorpha halys Stål. Proteomics 1800436:2-5. https://doi.org/10.1002/ pmic. 201800436

Serteyn L, Ponnet L, Saive M et al (2019) Changes of feeding behavior and salivary proteome of brown marmorated stink bug when exposed to insect - induced plant defenses. Arthropod Plant Interact 14:101-112. https://doi.org/10.1007/s11829-019-09718-8

Serteyn L, Quaghebeur C, Ongena M et al (2020) Induced systemic resistance by a plant growth-promoting rhizobacterium impacts development and feeding behavior of aphids. Insects 11:234. https://doi.org/10.3390/insects11040234

Sharma A, Khan AN, Subrahmanyam S et al (2014) Salivary proteins of plant-feeding hemipteroids-implication in phytophagy. Bull Entomol Res 104:117-136. https://doi.org/10.1017/S000748531 3000618

Stahl E, Hilfiker O, Reymond P (2018) Plant-arthropod interactions: who is the winner? Plant J 93:703-728. https://doi.org/10.1111/ tpj.13773

Tahir HAS, Gu Q, Wu H et al (2017) Bacillus volatiles adversely affect the physiology and ultra-structure of Ralstonia solanacearum and induce systemic resistance in tobacco against bacterial wilt. Sci Rep 7:1-15. https://doi.org/10.1038/srep40481

Tang QL, Ma KS, Hou YM, Gao XW (2017) Monitoring insecticide resistance and diagnostics of resistance mechanisms in the green peach aphid, Myzus persicae (Sulzer) (Hemiptera: Aphididae) in China. Pestic Biochem Physiol 143:39-47. https://doi.org/10. 1016/j.pestbp.2017.09.013

Tang T, Wu C, Li J et al (2012) Stress-induced HSP70 from Musca domestica plays a functionally significant role in the immune system. J Insect Physiol 58:1226-1234. https://doi.org/10.1016/j. jinsphys.2012.06.007 van Bel AJE, Will T (2016) Functional evaluation of proteins in watery and gel saliva of aphids. Front Plant Sci 7:1-19. https://doi.org/ $10.3389 /$ fpls.2016.01840

Van Loon LC (2007) Plant responses to plant growth-promoting rhizobacteria. Eur J Plant Pathol 119:243-254. https://doi.org/10.1007/ s10658-007-9165-1

Wallner AM, Hamilton GC, Nielsen AL et al (2014) Landscape factors facilitating the invasive dynamics and distribution of the brown marmorated stink bug, Halyomorpha halys (Hemiptera: Pentatomidae), after arrival in the United States. PLoS ONE 9:e95691. https://doi.org/10.1371/journal.pone.0095691

Wermelinger B, Wyniger D, Forster B (2008) First records of an invasive bug in Europe: Halyomorpha halys Stal (Heteroptera: Pentatomidae), a new pest on woody ornamentals and fruit trees? Mitteilungen Der Schweizerischen Entomol Gesellschaft 81:1-8

Wojda I (2017) Temperature stress and insect immunity. J Therm Biol 68:96-103. https://doi.org/10.1016/j.jtherbio.2016.12.002

Wu L, Huang Z, Li X et al (2018) Stomatal closure and SA-, JA/ETsignaling pathways are essential for Bacillus amyloliquefaciens FZB42 to restrict leaf disease caused by Phytophthora nicotianae in Nicotiana benthamiana. Front Microbiol 9:1-8. https://doi.org/ 10.3389/fmicb.2018.00847

Xie S, Jiang H, Ding T et al (2018) Bacillus amyloliquefaciens FZB42 represses plant miR846 to induce systemic resistance via a jasmonic acid-dependent signalling pathway. Mol Plant Pathol 19:1612-1623. https://doi.org/10.1111/mpp.12634

Xie S, Yu H, Li E et al (2019) Identification of miRNAs involved in Bacillus velezensis FZB42-activated induced systemic resistance in maize. Int J Mol Sci 20:5057. https://doi.org/10.3390/ijms2 0205057

Xie Y, Wu L, Zhu B et al (2017) Digital gene expression profiling of the pathogen-resistance mechanism of Oryza sativa 9311 in response to Bacillus amyloliquefaciens FZB42 induction. Biol Control 110:89-97. https://doi.org/10.1016/j.biocontrol.2017.04. 009

Zehnder G, Kloepper J, Tuzun S et al (1997) Insect feeding on cucumber mediated by rhizobacteria-induced plant resistance. Entomol Exp Appl 83:81-85. https://doi.org/10.1023/A:10029 07604294

Zhu G, Bu W, Gao Y, Liu G (2012) Potential geographic distribution of brown marmorated stink bug invasion (Halyomorpha halys). PLoS ONE 7:e31246. https://doi.org/10.1371/journal. pone.0031246 